\title{
University Students' Preparation towards Building Knowledge Economy in Africa: A Case of Universities in Ghana
}

\author{
Frank Quansah $^{1} \&$ Ebenezer Appiah $^{2} \&$ Vera Rosemary Ankoma-Sey ${ }^{3}$
}

\author{
${ }^{1}$ Department of Education and Psychology, University of Cape Coast, Ghana \\ ${ }^{2}$ Economics Department, University of Cape Coast, Ghana \\ ${ }^{3}$ College of Distance Education, University of Cape Coast, Ghana \\ Correspondence: Frank Quansah, University of Cape Coast, Ghana. \\ Email: frank.quansah1@ @stu.ucc.edu.gh
}

Received: June 9, $2019 \quad$ Accepted: August 21, $2019 \quad$ Online Published: September 1, 2019

doi: 10.23918/ijsses.v6i1p38

\begin{abstract}
For a country to develop, universities need to prepare students to be confident in facing the demands of the contemporary world of work. This paper focuses on examining how well universities are preparing students in Ghana in building a knowledge economy. The paper further explored the relationships among university preparation, students' preparation, and confidence of students. Using a cross-sectional survey design, data was gathered from 690 students from three public universities in Ghana, through a multi-stage sampling technique. A closed-ended questionnaire was used as the main data collection instrument. It was found that students prepared themselves towards a knowledge economy. Although the universities made efforts in preparing students, there were still lapses in preparing students towards a knowledge economy. Further analysis revealed that students were not confident enough to face the demands of a knowledge economy. Analysis from the mediation analysis using bootstrapping approach (5000 bootstrap samples), revealed that university preparation of students significantly mediated the relationship between students' personal preparation and confidence level of students, $b=.0798$, CI [.0427-.1189]. The authors, by their findings, called for innovative and practical teaching and learning in various universities in Ghana by lecturers and students.
\end{abstract}

Keywords: Knowledge Economy, University Preparation, Students Preparation, Globalisation

\section{Introduction}

For all nations, the foundation of economic revitalisation is knowledge. The knowledge-based economy is explained by The Organization for Economic Co-operation and Development (OECD) (2010) as an economy where "the manufacturing, distribution and utilisation of technology and information are solutions to fiscal activities and sustainable growth. In such an economy, creative and adaptive thinking skills of persons are heavily relied upon to develop answers for prevailing problems in the society (Salem, 2014). A knowledge-based economy refers to economy strictly centred on production (i.e., creation), delivery and utilisation of information and knowledge (Global, 2004). The World Bank (2010) highlighted that knowledge economy has four interrelated pillars: (1) economic and institutional regime; (2) education and skills; (3) information and communication technology; (4) innovative system. The World Bank (2010) report further indicated that education plays a crucial role in all the pillars. In other words, knowledge economy heavily depends on human capital as the key source of innovation and novel ideas via 
communication and communication technology (OECD, 2010). This calls for increased demand for a skilful workforce as well as unceasing intensification in joblessness of labour that is unskilled (Mustapha, Karim, Yasin, Yamat, Muhammad, \& Takriff, 2008). As a result, higher education and information communication technology has become very essential for economic development (Tilak, 2003; Kefela, 2010; Olssen \& Peters, 2005; Kurtic \& Donlagic, 2012).

Ghana, a developing country as South Africa and Malaysia, has been unsuccessful in achieving her knowledge-societal objectives albeit sharing a continent with South Africa and that both Ghana and Malaysia were colonized by the British and became independent in the same year, 1957 (Alagidede, BaahBoateng \& Nketiah-Amponsah, 2013; Boateng \& Ofori-Sarpong, 2002; Dabalen, Nielsen, \& Rosholm, 2001; Kefela, 2010). This suggests that Ghana if was doing well, should have achieved knowledge economy. Kefela (2010) also confirmed a greater proportion of the knowledge economy characteristics in Ghana were lacking irrespective of the existence of natural resources which are mainly exported to foreign nations in unprocessed form. These raw products are processed internationally and sent back to Ghana to be sold.

Moreover, the level of education in Ghana, for example, is generally low. According to the Ghana Statistical Service (2013), 28.5 percent of the working-age populace had no formal education, 48 percent were educated to the basic education level, 21 percent had Senior High School education, and 3 percent have been educated to the university level. This suggests that a larger proportion of the working population did not have a Senior High School education or even university education. This becomes a concern as to whether these working population could really help build a knowledge economy. Again, the report from the study on "The Ghana ICT for Accelerated Development", it was revealed that Ghana in contemporary time is challenged with human resource competence in Information and Communication Technology (ICT) skills (Kurtic \& Donlagic, 2012).

The theory of human capital theory regards training and education as an investment that can bring about public as well as private proceeds through increasing knowledge and information for the development of economies and progress of society (Tilak, 2003). The education system is responsible for producing skilled workers that are needed within the new knowledge economy (Mustapha et al., 2008). Daggash (2008) has argued that schooling, as well as human capital creation, may be the cause of both the changes in the productiveness of labour and modifications in technology that have been noted lately in most places on earth. Economically, the argument that supports knowledge-based training is associated with what is really needed by the current state of the economy (Kefela, 2010).

For any nation, universities play an essential role in the attainment of a knowledge economy. Supposedly, the universities are expected to be drivers of creativity and key agents of economic advancement (Salem, 2014). Several policymakers, subsequently, have labelled universities as "factories of knowledge production" with greatly unused reservoirs of theoretically commercialised knowledge which are supposed to be tapped by the industries (Wolfe \& Bramwell, 2008). Universities are not only mandated with the training of highly qualified scholars; they are also supposed to attract aptitudes from different places to the indigenous communal (Haupt, 2003; Wolfe \& Gertler, 2004). 
Alagidede, Baah-Boateng and Nketiah-Amponsah (2013) argued that the quality of university education has been a concern to major stakeholders in education. Alagidede et al. (2013) lamented that employers raised numerous grumble concerning the calibre of people trained in various educational institutions. Despite the increase in the number of private and public universities, there it seems that the training of human resource is not adequate. According to Baah-Boateng (2013), the tertiary education system in Ghana has now dominated by the desire to obtain 'certificates' instead of skill acquisition. Studies have discovered that the training provided by the tertiary institutions in Ghana mismatches the demands of the labour market (Boateng \& Ofori-Sarpong, 2002; Dabalen, Nielsen, \& Rosholm, 2001). In Boateng and Ofori-Sarpong's (2002) study, they revealed that the academia-industry collaboration in Ghana is tepid. Gondwe and Walenkamp (2011) also alluded to the fact that there exist little training departments in Ghanaian universities who equip students with relevant skills needed to fit in the labour market. Investigations by Ravinder (2010), and Kurtic and Donlagic (2012) reiterated that the Ghanaian education system "continues to produce employed graduate, semi-skilled and unskilled for employers with relatively few chances.

In a study by Quansah and Asamoah (2019), university students reported that assessment in their various institutions did not examine practical skills and as well did not motivate them in the application of what has been taught. According to the students, they felt the universities are not helping them enough to prepare for the world work because for them to pass, they have to memorise whatever has been taught. In a similar study, Quansah, Ankoma-Sey and Asamoah (2019) revealed that university graduate confirmed that back in school, they did not receive much experiential training in their respective field. Quansah et al. (2019) further discovered that the university graduate felt they lacked practical skills when they left school and thus, were not so confident in facing the world of work. In Mustapha et al.'s (2008) study, students also had low to moderate confidence because they felt they have prepared themselves for the world of work

Numerous pieces of evidence have been provided in earlier discourse to show that Ghana is challenged with her ability to attain a knowledge economy. Of course, it does seem that university students are not prepared, perhaps, because they feel the universities are not doing enough to prepare them to face the knowledge economy (Mustapha et al., 2008). This might account for the low confidence of students in facing the world of work. It can be argued that if universities are training students to apply knowledge in diverse situations, students would also do well to prepare themselves thereby boosting their confidence to face the dynamic world of work. Based on these observations in the literature, a conceptual framework was developed to explain the relationships that exist among the variables in the study (Figure 1). 


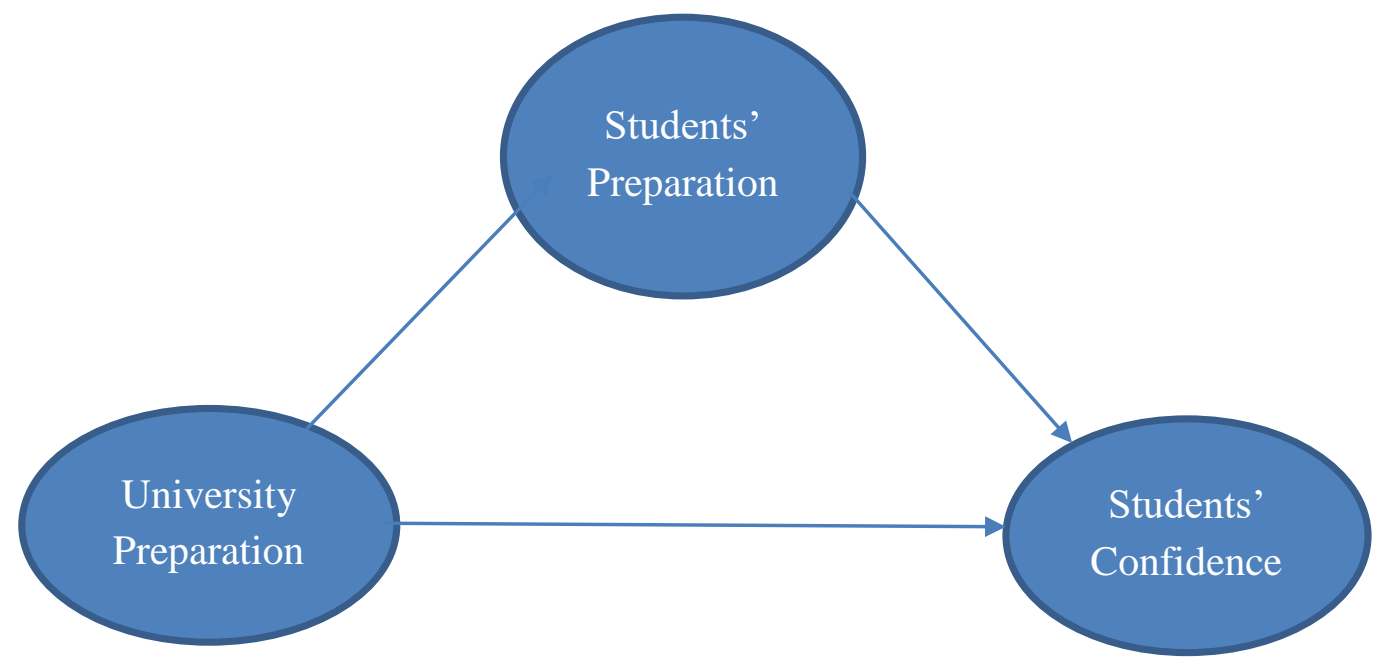

Figure 1: The relationships that exist among the variables in the study

The study raised a number of questions to guide the conduct of the study:

1. What preparation have students made towards the knowledge economy?

2. What role has the university played in preparing students towards the knowledge economy?

3. How confident are university students in facing the knowledge economy?

4. How students' preparation influences the relationship between university preparation and confidence to face the world of work?

\section{Research Methods}

The study utilised a cross-sectional survey design with the focus on obtaining answers to a series of questions which are carefully planned and given out to participants (Fraenkel \& Wallen, 2003). The study covered university undergraduate students at Kwame Nkrumah University of Science and Technology, University of Cape Coast and University of Ghana (Legon). These three institutions were used as the target population since they train the largest percentage of graduates in the country. Data was collected from $3^{\text {rd }}$ and $4^{\text {th }}$ year undergraduate students because we believed that these students have had adequate training in their various universities to be able to provide meaningful information in line with this study.

The multi-stage sampling technique was used to sample 760 students from three public universities. Questionnaire (5-point Likert Scale) was used to gather data from the sample. Finally, 690 questionnaires were correctly responded to and returned resulting in a return rate of $90.8 \%$. In analysing the data, descriptive statistics such as frequencies, percentages, mean and standard deviation were used. Mediation analysis using bootstrapping approach by Hayes was used to further analyse the data gathered. Specifically, 5000 bootstrap samples were used for bias-corrected bootstrap confidence intervals. The level of confidence was $95 \%$ with alpha level .05 .

\section{Presentation of Findings}

The presentation of the results was done in line with the questions raised in the introductory part of this paper. 


\subsection{Students Preparation towards Knowledge Economy}

The results, as shown in Table 1, revealed that majority of the respondents read extensively on current trending matters $(\mathrm{M}=3.59, \mathrm{SD}=.86)$. The greater proportion of the respondents indicated that they have equipped themselves with the pre-requisite skills to face the demands of the world of work $(\mathrm{M}=3.58$, $\mathrm{SD}=.99)$. The respondents also pointed out that they are familiar with the use of computer and IT $(\mathrm{M}=3.90$ $\mathrm{SD}=.94)$. Again, the larger proportion of the respondents indicated that they have good oral and written communication skills $(\mathrm{M}=4.03, \mathrm{SD}=.73)$ and as well have the ability to analyse data/situations; propose solutions and make decisions $(\mathrm{M}=3.83, \mathrm{SD}=.80)$.

Table 1: Students Preparation towards Knowledge Economy

\begin{tabular}{lcc}
\hline Statements & Mean & SD \\
\hline $\begin{array}{l}\text { I read extensively on current trending matters in my area of } \\
\text { study }\end{array}$ & 3.59 & .86 \\
$\begin{array}{l}\text { I have equipped myself with the pre-requisite skills to face the } \\
\text { demands of the world of work }\end{array}$ & 3.58 & .99 \\
$\begin{array}{l}\text { I am familiar with the use of computer and IT } \\
\begin{array}{l}\text { I have learned to become excellent in oral and written } \\
\text { communication skills }\end{array}\end{array}$ & 3.90 & .94 \\
$\begin{array}{l}\text { Ihave the ability to analyse data/situations; propose solutions and } \\
\text { make decisions }\end{array}$ & 3.83 & .83 \\
\hline Mean of Means & 3.79 & .93 \\
\hline
\end{tabular}

\subsection{The Role of Universities in Preparing Students towards K-Economy}

As shown in Table 2, the majority of the respondents believed the university education provides students with basic skills in ICT $(\mathrm{M}=3.39, \mathrm{SD}=1.17)$ and that university education helps students develop numeracy and IT skills $(\mathrm{M}=3.40, \mathrm{SD}=1.09)$. It was also discovered that university education helps students acquire a high level of self-discipline and the ability to function in a team $(\mathrm{M}=4.12, \mathrm{SD}=0.77)$. Most of the respondents also indicated that specific courses on how to face the challenges of the new era (k-economy) are not taught at the university $(\mathrm{M}=3.26, \mathrm{SD}=1.21)$. The respondents were of the view that university education mainly focused on reading and writing rather than providing students with skills relevant to the current global economy $(\mathrm{M}=3.67, \mathrm{SD}=1.20)$. 
Table 2: The Role of University in Preparing Students towards K-economy

\begin{tabular}{lcc}
\hline Statement & Mean & SD \\
\hline University education provides students with basic skills in ICT. & 3.39 & 1.17
\end{tabular}

The university education helps students develop numeracy and IT skills $\quad 3.40 \quad 1.09$

$\begin{array}{llll}\text { University education helps students acquire a high level of self- } & 4.12 & 0.77\end{array}$

discipline and the ability to function in a team

Specific course on how to face the challenges of the new era $(k-3.26 \quad 1.21$ economy) are not taught at the university

$\begin{array}{lll}\text { The university education is mainly of reading and writing rather than } & 3.67 & 1.20\end{array}$ providing students with skills relevant to the current global economy

\begin{tabular}{lll}
\hline Mean of Means & 3.57 & 1.13
\end{tabular}

\subsection{Confidence Level of Students in Facing the Demands of Knowledge Economy}

Table 3 presents responses on the confidence levels of the respondents. More than half of the respondents (54.6\%) claim that they have a moderate level of confidence to face the needs of globalisation and knowledge economy. The results also revealed that $25 \%$ of the respondents have low confidence level while $20.0 \%$ of the respondents stated that they have a high confidence level to face the needs of the economy.

Table 3: Confidence Level of Respondent

\begin{tabular}{lcc}
\hline Confident level & Frequency & Percentage \\
\hline High & 138 & 20.0 \\
Moderate & 377 & 54.6 \\
Low & 175 & 25.4 \\
\hline Total & 690 & 100.0 \\
\hline
\end{tabular}

\subsection{Universities Role, Students Personal Preparation and Confidence of Students}

The analysis in Table 4 found that university preparation predicted their confidence level in facing the needs of a knowledge economy, $b=.161, t=9.424, p<.001$, such that $2.3 \%$ of the variances in the confidence level of students was explained by university preparation, $F(1,688)=16.32, p<.001$. The results showed that university preparation explained $21.6 \%$ of the variances in students preparation, $F(1$, $688)=189.50, p<.001$. When controlling for students' preparation, university preparation failed to significantly predict confidence, $b=.082, t=1.828, p=.068$. 
Table 4: Predictions of Students preparation, University Preparation, and Confidence of Students

\begin{tabular}{|c|c|c|c|c|c|c|c|c|c|c|}
\hline \multirow[t]{2}{*}{ Model } & & \multirow{2}{*}{$\begin{array}{c}b- \\
\text { value }\end{array}$} & \multirow[b]{2}{*}{$S E$} & \multirow[t]{2}{*}{$t$-value } & \multirow{2}{*}{$\begin{array}{c}p- \\
\text { value }\end{array}$} & \multicolumn{5}{|c|}{ Model Summary } \\
\hline & & & & & & $\mathrm{R}^{2}$ & $F$ & df1 & df2 & $p$ \\
\hline \multirow[t]{4}{*}{ One } & Constant & 1.732 & .135 & 12.831 & $.000 *$ & \multirow{4}{*}{.216} & \multirow{4}{*}{189.50} & \multirow{4}{*}{1} & \multirow{4}{*}{688} & \multirow{4}{*}{$.000 *$} \\
\hline & & & & & & & & & & \\
\hline & University & .485 & .035 & 13.77 & $.000 *$ & & & & & \\
\hline & Preparation & & & & & & & & & \\
\hline \multirow[t]{3}{*}{ Two } & Constant & 1.44 & .153 & 9.424 & $.000 *$ & \multirow{3}{*}{.023} & \multirow{3}{*}{16.32} & \multirow{3}{*}{1} & \multirow{3}{*}{688} & \multirow{3}{*}{$.000 *$} \\
\hline & University & .161 & .040 & 4.040 & $.001 *$ & & & & & \\
\hline & Preparation & & & & & & & & & \\
\hline \multirow[t]{5}{*}{ Three } & Constant & 1.159 & 169 & 6.862 & $.000 *$ & \multirow{5}{*}{.044} & \multirow{5}{*}{15.698} & \multirow{5}{*}{2} & \multirow{5}{*}{687} & \multirow{5}{*}{$.000^{*}$} \\
\hline & University & .082 & .045 & 1.828 & $.068 *$ & & & & & \\
\hline & Preparation & & & & & & & & & \\
\hline & Students' & .164 & .043 & 3.840 & $.001 *$ & & & & & \\
\hline & Preparation & & & & & & & & & \\
\hline
\end{tabular}

Criterion: Model 1- Students' Preparation; Model 2- Confidence; Model 3- Confidence

*significant at .05 level

Table 5: Total Effect, Direct Effect, and Indirect Effect

\begin{tabular}{|c|c|c|c|c|c|c|}
\hline & \multirow[b]{2}{*}{ Effect } & \multirow[b]{2}{*}{ SE } & \multirow[b]{2}{*}{$\begin{array}{c}\mathrm{t}- \\
\text { value }\end{array}$} & \multirow[b]{2}{*}{$\begin{array}{c}\mathrm{p}- \\
\text { value }\end{array}$} & \multicolumn{2}{|c|}{$\mathrm{CI}$} \\
\hline & & & & & $\begin{array}{c}\text { Lower } \\
\text { Limit }\end{array}$ & $\begin{array}{l}\text { Upper } \\
\text { Limit }\end{array}$ \\
\hline Total effect of $\mathrm{X}$ on $\mathrm{Y}$ & .161 & .040 & 4.040 & $.001 *$ & .083 & .240 \\
\hline Direct effect of $X$ on $Y$ & .082 & .0435 & 1.828 & $.001 *$ & -.006 & .169 \\
\hline Indirect effect of $\mathrm{X}$ on $\mathrm{Y}$ & Effect & $\begin{array}{c}\text { Boot } \\
\text { SE }\end{array}$ & \multicolumn{2}{|c|}{ BootLLCI } & \multicolumn{2}{|c|}{ Boot ULCI } \\
\hline Student Preparation (M) & .0798 & .0193 & \multicolumn{2}{|c|}{.0427} & \multicolumn{2}{|c|}{.1189} \\
\hline
\end{tabular}

$\mathrm{X}$ - University Preparation; Y-Confidence; *significant at .05 level

The results, as shown in Table 5, discovered that university preparation is directly related to student preparation. Further analysis showed that student preparation significantly mediated the relationship between university preparation and the confidence level of students in facing the demands of a knowledge economy, $b=.0798, C I$ [.0427-.1189]. Further analysis shows that for universities to prepare students to be confident, students also have to prepare themselves. In other words, even if the university prepares their students very well, they will not be confident unless the students also do some preparations.

\section{Discussion}

The results showed that students' preparation level towards the knowledge economy was high. The study found that students read extensively on current trending matters, are familiar with computer and IT as well as possess a problem-solving ability. Like this study, Mustapha et al (2008) also reiterated that students keep abreast on modern issues, have knowledge IT, possesses mental readiness and communication abilities in order to compete in a K-economy environment. The high preparation of students towards the 
knowledge economy implies that they are likely to acquire the relevant features required to face the challenges of the new era. This will enable them to compete with others in this new era. Studies have shown that it is important for a knowledge worker to possess special attributes including the ability to make sense out of a piece of information to solve problems (Alavi \& Leidner, 2001; Brătianu \& Dinca, 2010). It is not surprising to know that students learnt to become excellent in oral and written communication skills. The importance of communication skills in today's job market cannot be overemphasized. The corporate world today requires personnel with good communication skills since the ability to communicate well with others attract customers and promote the growth of businesses.

The study found that university education helps students acquire basic skills in ICT as well as develop numeracy and IT skills. Literature has also shown higher educational institutions trains students in IT (Bansal et al., 2010). The development of IT skills increases personnel's ability to survive in the current global knowledge economy. The study also found that university education enables students to acquire a high level of self-discipline and the ability to function in a team. The result of this study is not surprising since the role of education in developing a knowledge worker cannot be underestimated. In line with the findings of the study, we agree with Ravinder (2010) who argued that universities are noted to be crucial in preparing students to face the world market.

The study, however, revealed some negative perception regarding how the university prepares them to face the world market. The students reported that university education mainly focused on reading and writing rather than providing students with skills relevant to the current global economy. This finding was reflected in Quansah and Asamoah (2019) study where students reported that the school system encouraged rote learning. Another finding revealed that specific courses on how to face the challenges of the new era (k-economy) are not taught at the universities. This is a bit surprising since most tertiary schools in Ghana aim at developing personnel that can create jobs and not rely solely on government for employment. To combat the widespread of the unemployed graduate in Ghana, entrepreneurship and other courses that are vital to the global business are taught at various universities in the country. The findings of the study contradict the views of Ravinder (2010) that tertiary educational organisation ought to develop a tough, vibrant foundation to support the new economy and also to offer the required knowledge for social movement and economic development crucial to economies all over the world.

The results of the study revealed that majority of the respondents are not confident enough to face the challenges of the global knowledge economy. This was not different from the findings of Mustapha et al. (2008) who revealed that majority of the respondents ( 58 percent) revealed that the university education offers students with inadequate or limited preparation to face the challenges of the global knowledge economy. This low confidence level of students can be attributed to the fact that the university education placed much emphasis on reading and writing rather than providing students with skills relevant to the current global economy and since not enough specific courses on how to face the challenges of the new era (k-economy) are not taught at the university. It has been observed that training programmes that are important as concerns skills at various higher educational institutions are not enough and that most of the programmes are also not in alignment with the requirement of the global labour market. Literature has proven that the skills provided by the educational institutions are incompatible with the demand of the labour market (Gondwe \& Walenkamp, 2011; Haupt, 2003). This is also a key reason for the low confidence level of students to face the challenges of a knowledge economy. 
The findings of this study also revealed that the university plays a crucial role if students are to prepare themselves and become confident in facing the knowledge economy. It was realised that although the university preparation was a significant predictor of student preparation, university preparation was not enough to build the confidence of the students. This highlights the essence of both university and personal student preparation in building confidence. This reflects the findings of Quansah et al.'s (2019) study which found that inadequate preparation by the university as well as individual student preparation resulted in a gap between the academia and the industry.

\section{Conclusion and Recommendations}

Findings from the study bring forth the perception that students are generally preparing themselves for a knowledge economy. We believe an attempt to enrol in university programmes by individuals is the first step in students preparing themselves. This has been seen in the increasing enrolment in both undergraduate and postgraduate programmes in these universities. However, this preparation is not substantial if their universities fail to play a role in preparing and building the confidence of students. This was obvious in the findings which revealed that students' preparation was not enough to build the confidence of students in facing the demands of a knowledge economy. It is prudent to state that both the university and the students have equally important roles to play in building the confidence to face the contemporary world of work. This should go beyond classroom teaching and learning, and writing of "paper and pencil" examinations. It appears that the university preparation, as reported by the students, is not enough to supplement their personal preparation in building their confidence.

There is a call, by the findings of this paper, for innovative and practical teaching and learning in various universities in Ghana by lecturers and students. This should include using authentic assessment in evaluating students learning, pragmatic teaching approaches, and mounting of courses relevant to the contemporary world of work. The management of universities is encouraged to liaise with industry players in refining already existing programmes and mounting new ones as well. The Academic Board Committees of universities in Ghana should also ensure that university education does not place much emphasis on just reading and writing but providing students with relevant skills to meet the demands of the current global economy. It must be noted that our findings only reflect the perceptions of the students. Therefore, further study is needed to do a proper assessment of university structures, policies and programmes to find out how well universities in Ghana are preparing students to face the knowledge economy.

\section{References}

Alagidede, P., Baah-Boateng, W., \& Nketiah-Amponsah, E. (2013). The Ghanaian economy: An overview. Ghanaian Journal of Economics, 1, 4-34.

Alavi, M., \& Leidner, D. E. (2001). Knowledge management and knowledge management systems: Conceptual foundations and research issues. MIS quarterly, 107-136.

Baah-Boateng. (2013). Determinants of Unemployment in Ghana. African Development Review, 25(4), 385-399.

Boateng, K., \& Ofori-Sarpong, E. (2002). Analytical study of the labour market for tertiary graduates in Ghana. Accra: National Council for Tertiary Education and the National Accreditation Board Project. Accra, Ghana. 
Brătianu, C., \& Dincă, V. M. (2010). Knowledge economy dimensions. Review of International Comparative Management, 11(2), 210-221.

Dabalen, A., Nielsen, H. S., \& Rosholm, M. (2001). Labour markets and enterprise training in African manufacturing. Washington DC, World Bank.

Daggash, M. S. (2008). Roundtable Discussion on Energy Infrastructure Development. In NAEE/IAEE Conference, NAEE/IAEE International Conference, April 29-30, 2008. International Association for Energy Economics.

Danjuma, I., \& Rasli, A. (2013). Higher education and knowledge economy: A focus on Nigeria. Sains Humanika, 64(3).

Dorinela, C. (2011). The knowledge based society and economy. Ovidius University Annals, Economic Sciences Series, 11(2), 303-306.

Fraenkel, J. R., \& Wallen, N. E. (2003). How to design and evaluate research in education ( $5^{\text {th }}$ ed.). Boston: McGraw-Hill.

Ghana Statistical Service. (2013). 2010 Population and housing Census. National Analytical report, Ghana Statistical Service.

Global, A. (2004). Intellectual property law in India: Challenges and promises organized by Symbiosis International Educational Centre (Deemed University) Symbiosis Society's Law College, November 20th,(2004), Pune.

Gondwe, M., \& Walenkamp, M. (2011). Alignment of higher professional education with the needs of the local labour market: The case of Ghana. Hague: The Hague University of Applied Sciences.

Haupt, T. C. (2003). Student attitudes towards cooperative construction education degree level skills for construction and surveying students' experiences. The Australian Journal of Construction Economics and Building, 3(1), 31-42.

Kefela, G. T. (2010). Knowledge-based economy and society has become a vital commodity to countries. International NGO Journal, 5(7), 160-166.

Kurtić, A., \& Đonlagić, S. (2012). Determining key factors for knowledge economy development in Bosnia and Hercegovina. Management, Knowledge and Learning, 116-127.

Mustapha, R., Karim, F., Mohd Yasin, R., Azman, N., Yamat, H., Muhammad, A. W., \& Takrif, S. (2008). K-Economy and Globalisation: Are Our Students Ready? Jurnal Personalia Pelajar, 11, 1-23.

Olssen, M., \& Peters, M. A. (2005). Neoliberalism, higher education and the knowledge economy: From the free market to knowledge capitalism. Journal of Education Policy, 20(3), 313-345.

Organization for Economic Co-operation and Development [OECD]. (2010). The knowledge-based economy: A set of facts and figures. Paris: OECD.

Quansah, F., \& Asamoah, D. (2019). Chew, pour, pass, and forget: Students' perception of authentic assessment in universities in Ghana. Social Sciences and Humanities Journal, 3(3), 901-909.

Quansah, F., Ankoma-Sey, V. R., \& Asamoah, D. (2019). The gap between the academia and industry: Perspectives of university graduates in Ghana. International Journal of Education and Research, 7(3), 63-72.

Ravinder, R. (2010). Emerging trends of higher education in developing countries. Economics, 57, 301315.

Salem, M. I. (2014). The role of universities in building a knowledge-based economy in Saudi Arabia. International Business \& Economics Research Journal, 13(5), 1047-1056.

Tilak, J. B. (2003). Higher education and development in Asia. Journal of Educational Planning and Administration, 17(2), 151-173.

Wolfe, D. A., \& Bramwell, A. (2008). Universities and regional economic development: The entrepreneurial University of Waterloo. Research Policy, 37(8), 1175-1187.

Wolfe, D. A., \& Gertler, M. S. (2004). Local social knowledge management: Community actors, institutions and multilevel governance in regional foresight exercises. Futures, 36, 45-65 
International Journal of Social Sciences \& Educational Studies ISSN 2520-0968 (Online), ISSN 2409-1294 (Print), September 2019, Vol.6, No.1

World Bank Institute. (2010). Measuring knowledge in the world's economies: Knowledge assessment methodology and knowledge economy index. Washington: Knowledge for Development (K4D) Program. 